\title{
Analyzing the Mental Health of Students in Dealing with the Coronavirus Disease Pandemic (Covid-19)
}

\author{
Muhamad Chamdani ${ }^{*}$, Umi Mahmudah², Siti Fatimah ${ }^{3}$ \\ ${ }^{1}$ Sebelas Maret University, Indonesia \\ 2Institut Agama Islam Negeri Pekalongan, Indonesia \\ ${ }^{3}$ Institut Agama Islam Nahdlatul Ulama Kebumen, Indonesia \\ *e-mail: muhamad chamdani@staff.uns.ac.id
}

\begin{abstract}
This study aims to analyze mental health and anxiety levels during the COVID-19 pandemic. This study focused on students who were forced to study at home by e-learning. This study used as many as 210 students from junior high school, senior high school, and university levels which were selected randomly. Then, this study used a mixed-method by combining quantitative and qualitative approaches. Multivariate analysis of variance (MANOVA) was used to obtain empirical results to compare mental health and anxiety levels based on student age groups. The analysis results revealed there was a positive and significant influence of the students' age group on mental health and anxiety levels during the outbreak of COVID-19. The analysis also concluded that students in the 12-15 years' age group had the worst mental health level. Meanwhile, students in the 20-25 years' age group are known to have the lowest anxiety level. Overall, this study found that Indonesian students experienced a decline in mental health and detected an increase in anxiety levels. The level of mental health and student anxiety has implications for their learning at home, which can lead to unsatisfactory learning outcomes.
\end{abstract}

Keywords: Mental Health, Anxiety, COVID-19

\section{Introduction}

One of the important aspects of child development was mental health (Mekonnen et al., 2020; Zajacova et al., 2020). Indonesian society has recently been hit by critical mental health problems related to various reports in the media about bullying, sexual violence, brawls, suicide, and even murder (Mahriza et al., 2020; Muhammad, 2019; Putri et al., 2020; Suryani, 2016). A study reported that a child who had good mental health tended to be an adult who was optimistic, independent, creative, and able to make an adequate contribution to their environment by using their capacity optimally (Pieh et al., 2020; Zajacova et al., 2020). Children and adolescents were increasingly susceptible to mental health problems amid the Covid-19 pandemic. The spread of COVID-19 has the potential to cause widespread concern in mental health problems (Cullen et al., 2020; Gavin et al., 2020; Ho et al., 2020; Lima et al., 2020; Moreno et al., 2020; Pierce et al., 2020; Ransing et al., 2020; Talevi et al., 2020; Torales et al., 2020). In 2020, The United Nations Children's Fund (UNICEF) surveyed on the understanding of COVID-19 and its symptoms and prevention of young people aged 15-30 years in Indonesia, involving all 34 provinces. By using the short message service (SMS) applications, 7,469 responses were obtained. $46 \%$ of respondents in this survey were males while female respondents were about $54 \%$. Then, the majority of respondents were in the age group of 15-24 years old. The survey results reported that $34 \%$ of respondents said they were afraid of COVID-19 and as many as $17 \%$ of respondents said they were very afraid (UNICEF, 2020).

The COVID-19 pandemic caused the entire world to face unprecedented global health and socio-economic crisis. School closures might affect the education and mental health of students (Bao et al., 2020; Lee, 2020; Martin \& Sorensen, 2020; Singh et al., 2020; Van Lancker \& Parolin, 2020). UNICEF reported that nearly 60 million children in Indonesia did not go to school because of COVID-19 and potentially increased the cases of sexual

\section{${ }^{*}$ Corresponding author.}

Received November 28, 2020; Accepted February 20, 2021; Available online December 25, 2021

This is an open access article under the CC BY-SA license. Copyright $(2021$ by Author. Published by Universitas Pendidikan Ganesha 
abuse and violence against children. The COVID-19 pandemic restricted children from social activities and interactions, resulting in unfavorable impacts on children's education and development (UNICEF, 2019). One of the most important aspects of children's development is mental health. In studies from high-income countries, emotional symptoms, and behavioral disorders of children (EBD) was influenced by many things, such as poorer social adaptation, physical welfare disorders, functional disorders, and poorer educational outcomes (Mekonnen et al., 2020). The crisis due to COVID-19 might leave children more vulnerable to violence and psychosocial pressure (Bodrud-Doza et al., 2020; Hamadani et al., 2020; Lahav, 2020).

One of the impacts felt by children during the COVID-19 pandemic was psychological (mental) pressure or commonly referred to as Mental Health and Psychosocial Support (MHPSS) (Pieh et al., 2020; Saha et al., 2021; Zajacova et al., 2020). For this reason, the IASC recommended integrated levels of COVID-19 emergency activities. These levels were aligned with the spectrum of mental health and psychosocial needs (UNICEF, 2020). These levels ranged from instilling social and cultural considerations in basic services to providing specific services for individuals with more severe conditions. Mental health is a state of wellbeing in which an individual realizes his or her abilities, can cope with the normal stresses of life, can work productively, and can make a contribution to his or her community (Fatimah \& Mahmudah, 2020; M. J. Savage et al., 2020). Mental health was a key component in the development of children's health, where children needed to be healthy to learn, grow, and lead productive lives (WHO, 2020; Wu et al., 2020). The U.S. government's mental health and mental health problems information on its website stated mental health included the emotional, psychological, and social well-being of each individual. Positive mental health enabled people to realize their full potential, be able to cope with life stresses, be able to work productively and make meaningful contributions to other people/their communities.

WHO recommended several ways to reduce children's stress during COVID-19, which were: First, Responding to children's reactions by supporting and listening to children's concerns and giving children love and more attention (Talevi et al., 2020; WHO, 2020). Second, giving children more time and attention because they needed them during difficult times, listening to children, communicating friendly and convincing them, giving children opportunities to play and relax. Third, Keeping children closed to their parents and family; 4) Maintaining their routine as much as possible, if needed helps them to make a new schedule in a new environment, ensuring they can play and relax safely (Fatimah \& Mahmudah, 2020; M. J. Savage et al., 2020). Fifth, providing children the facts about what has happened by explaining information clearly how to reduce the risk of being infected by the disease. It is important to use simple words so that they can digest and understand information precisely and accurately $(\mathrm{WHO}, 2020)$. There have been many studies analyzing the mental health of students in the midst of the COVID-19 pandemic (Ardan et al., 2020; Fatimah \& Mahmudah, 2020; Mechili et al., 2020; Megatsari et al., 2020; M. J. Savage et al., 2020; Son et al., 2020; Wang et al., 2020; Wu et al., 2020; Zhai \& Du, 2020). Furthermore, the WHO stated that 104 out of 1000 children aged 4-15 years, experience mental emotional disturbances (WHO, 2011). One of the factors that affected children's mental health was the lack of ability to adapt to their environment and experiences. A child who was unable to adapt to conditions and environmental changes tended to have an impact on poor mental health, such as the COVID-19 pandemic. Changes in extreme conditions were certainly not easy for everyone, especially children who were basically individuals who prefer the outdoors.

However, research on the same topic is still rarely found in Indonesian students related to their mental health amid the COVID-19 pandemic. The main objective of this study was to analyze mental health during the COVID-19 pandemic. This research focused on adolescent mental health in dealing with this crisis. Their anxiety levels at the time of the pandemic were also analyzed statistically. Both were analyzed and then compared based on the age group of the respondents. It is important to conduct in-depth research on the mental health of students who were forced to learn from home as a result of the rapid and widespread COVID-19. As a nation's asset for the future, students need to get proper attention so that they do not face difficulties in adapting to new learning styles during the 
outbreak of COVID-19. Then, this study might also be used as study material to reduce mental stress in children, especially during COVID-19.

\section{Method}

This study used a research method that was a mixture of quantitative and qualitative approaches. Both approaches were used together during the research process as a guide in data collection and analysis. Creswell \& Creswell stated that mixed methods focused on data collection and data analysis using quantitative and qualitative approaches in one study or series of studies (Creswell \& Creswell, 2018). Furthermore, this study used a sequential explanatory type in mixed methods, where the research tended to be more inclined to the quantitative process. Thus, the initial stage of this research was the collection and analysis of data using a quantitative approach. By using the results of the first stage, the second stage was carried out by collecting and analyzing data using a qualitative approach. In other words, this research prioritized quantitative approaches when qualitative approaches were used as additional data to produce a more in-depth discussion (Creswell \& Creswell, 2018). The quantitative approach was carried out using questionnaire distribution while the qualitative approach was carried out by observation and interviews.

To obtain empirical results of mental health, especially the mental health of students in Indonesia, this study distributed questionnaires to as many as 210 students randomly. The survey was conducted online by using the internet to students at junior high schools, senior high schools, and universities. This study adopted a mental health measurement instrument based on the Brief Symptom Inventory (BSI). Meanwhile, the instrument to measure respondents' anxiety levels was adapted from the Depression, Anxiety, and Stress Scale (DASS). To compare adolescent mental health and their anxiety level based on age groups; this study used a multivariate analysis of variance (MANOVA) approach. This method is similar to the analysis of variance (ANOVA) which is usually used to analyze the average differences between the two groups. The difference lied in the number of dependent variables used in the analysis. ANOVA uses only one dependent variable while MANOVA can involve more than one dependent variable in the average comparison test. There were three age groups analyzed in this study, where all respondents were students from junior high school, high school, and university levels. The first group was called the early adolescent group, where the age of this group was less than 15 years, which were between 12-15 years old. The second group was called the late adolescent group with ages between 15-19 years old. And the last group was called early adulthood, where their ages were between 20-25 years old.

\section{Result and Discussion}

\section{Results}

This section discussed empirical research findings based on statistical analysis. Mental health and anxiety levels due to the COVID-19 pandemic were analyzed based on the three age groups. They were the early adolescent, the late adolescent, and the early adult groups. As mentioned earlier, the quantitative approach was based on respondents' answers from the questionnaire. The general description of the respondents sampled in this study was as follows. The average age of respondents was 17 years with a standard deviation of 3 years. The youngest and oldest respondents were 12 and 25 years old, respectively. The majority of respondents were females (around $76.70 \%$ ) compared to male respondents who were only $23.30 \%$. Figure 1 illustrated the distribution of respondents by school levels. Figure 1 showed that respondents at the junior and senior high schools were $32.38 \%$ and $34.76 \%$, respectively whereas the respondents at the university level were $32.86 \%$. Based on data analysis, found that the level of mental health and anxiety of respondents were at the level of $77.78 \%$ and $70.37 \%$, respectively. These results indicated that respondents who were sampled in this study tended for mental health to decline. Then, the results of the analysis also indicated that their anxiety levels were relatively high. Based 
on data analysis, respondents at the age of fewer than 15 years (early adolescents) produced lower mental health levels than late adolescents (15-19 years) $76.96 \%$ ) and early adults (20-25 years) (81.96\%). Conversely, anxiety level in early adolescents was known to be the highest compared to others (32.70\%).

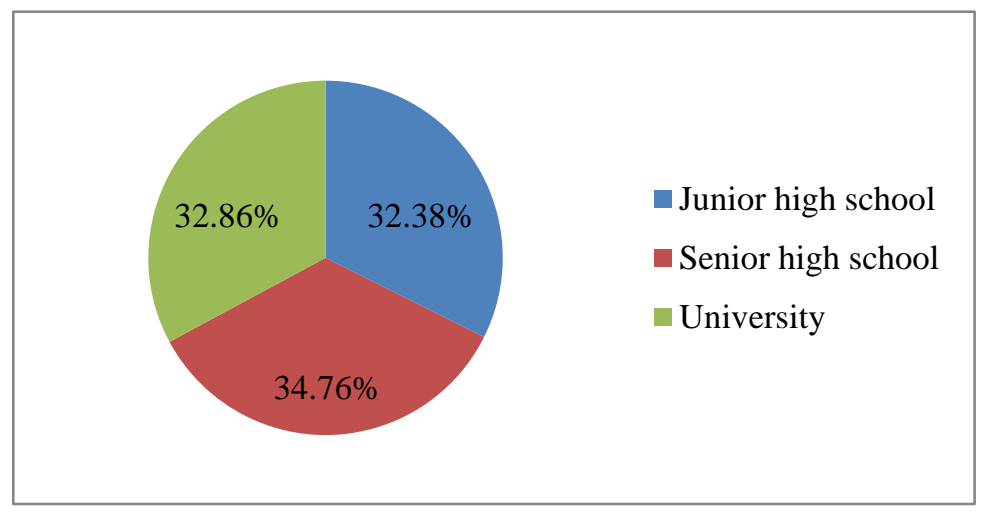

Figure 1. Proportion of respondents based on school level

The results of statistical analysis using MANOVA also suggested that the age group of students studying at home had a positive and significant effect on the two dependent variables, namely their level of mental health and anxiety. These results also indicated that different age groups had significantly different mean scores of mental health and anxiety levels. The value of Wilks' $\Lambda$ was $0.94 ; F(4,412)=3.11 ; p$-value $<0.05$; the multivariate $\eta^{2}=$ 0.81 . It was important to point out that the statistical value of $F$ was statistically significant, which indicated that there were significant differences between age groups in the linear combination of the two dependent variables used, namely mental health and anxiety levels. Then, the Partial Eta Squared value or the multivariate value $\left(\eta^{2}\right)$ was 0.81 , which indicated that $81 \%$ of the multivariate variance of the dependent variable can be related to the age group. The analysis results from table 5 also indicated that the age group significantly affected mental health with a $p$-value of 0.01 (less than 0.05 ) which means that the null hypothesis was rejected. Then, the age group also significantly affected the level of anxiety with a $p$-value of 0.01 (less than 0.05 ) and the null hypothesis was also rejected. This result indicated that the influence of the three age groups on the level of mental health and student anxiety was 0.81 or $81 \%$. In other words, as much as $81 \%$ of the age groups were able to explain the two dependent variables, namely mental health and student anxiety. The average difference in mental health and anxiety levels by age group was clearly illustrated in Figure 2.
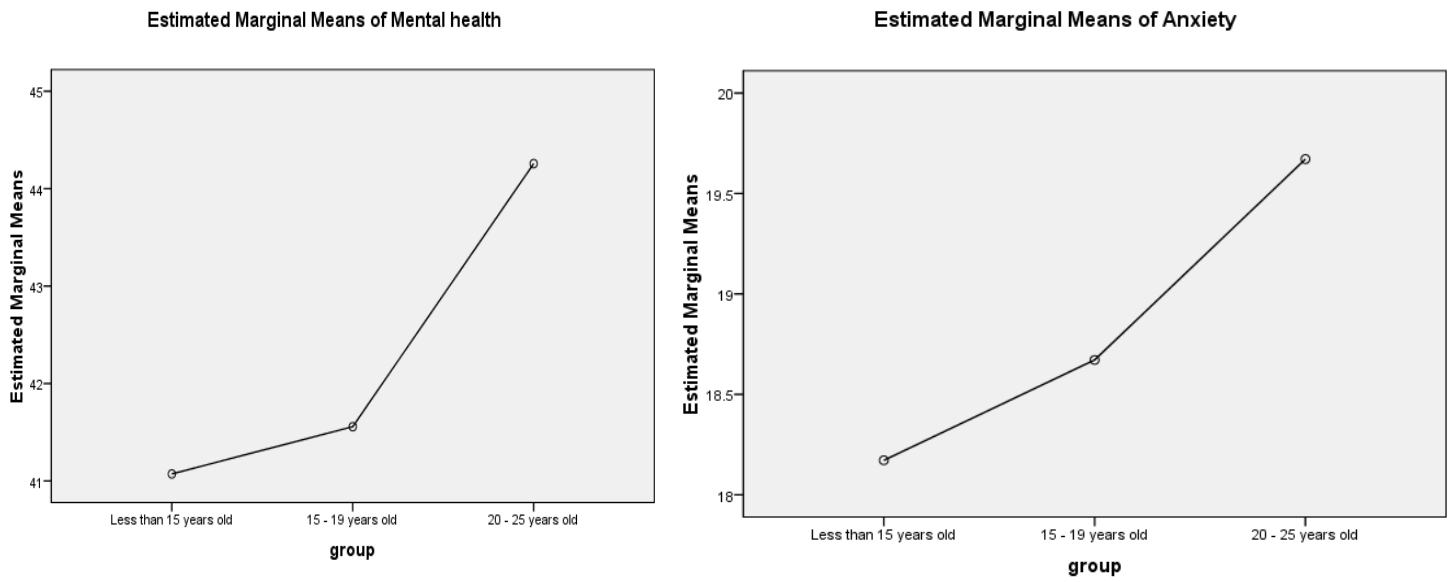

Figure 2. Estimated Marginal Means of Mental Health and Anxiety 
Figures 2 provided an illustration of the level of students' mental health and anxiety. From the two figures it can be seen that the age group used produced similar results based on the two dependent variables. Based on the analysis, it was found that the average level of health was statistically different between the age group of fewer than 15 years and the age group of 20-25 years ( $p$-value $=0.00$ ). However, it did not differ significantly between the age groups of less than 15 years and the age group of $15-19$ years $(p$-value $=0.66)$. The average level of health was statistically different between the age group of 15-19 years and the age group of $20-25$ years ( $p$-value $=0.01$ ). Furthermore, the post hoc test also showed that the age group of 20-25 years was found to be significantly different from the two age groups of less than 15 years and between 15-19 years, where the p-values were 0.00 and 0.01 , respectively. The average anxiety level was found to be significantly different between the age group of fewer than 15 years and the age group of 20-25 years ( $p$-value $=0.00$ ). However, the analysis also found that there was no significant difference between the age group of fewer than 15 years and the age group of $15-19$ years $(p$-value $=0.30)$. Then, the results of the post hoc test also found that the average anxiety level of the 15-19 year age group was significantly different from the 20-25 year age group. Furthermore, there were differences in the average level of anxiety in the age group of 20-25 years with the two age groups of less than 15 years and between 15-19 years, where the $p$-values were 0.00 and 0.04 , respectively.

In-depth analysis based on qualitative data can be described as follows. Analysis of the questionnaire found that the majority of respondents were detected as having symptoms of mental health decline. As many as $58.10 \%$ and $15.70 \%$ of respondents agreed and strongly agreed that they were upset and could not think positively because of COVID-19. Then, the majority of respondents (around 93.40\%) stated they had excessive solicitudes whereas $90.00 \%$ of respondents said their lives were unhappy because of COVID-19. Then, the questionnaire analysis also found respondents who agreed and strongly agreed that they felt pressured because of COVID-19 were $41.90 \%$ and $43.33 \%$, respectively. The analysis also indicated that the majority of respondents did not have enough rest. The majority of them (92.38\%) stated they could not rest in peace and comfort. These results indicate that the mental health of the majority of respondents was affected by COVID-19, which all affected their daily lives.

\section{Discussion}

The analysis found that the level of mental health of students while studying at home due to the Covid-19 pandemic was known to increase with their age group. The youngest age group (less than 15 years) produced the lowest average mental health score, namely 41.07. Then, the oldest age group (20-25 years) was also known to produce the highest average mental health score, which were 44.26. These results appeared to contradict a study which reported that the younger age group had better mental health literacy than the older group. Better literacy levels in mental health means that they had better knowledge and experience to identify mental health and thus facilitated prevention efforts (Hadjimina \& Furnham, 2017; Wu et al., 2020). However, the category of the young age group used in the Hadjimina \& Furnham research was $18-29$ years. Meanwhile, the age category was included in the second and third group categories in this study, namely the late adolescent group (between 15-19 years) and the early adulthood (between 20-25 years). Both of these phases were the phase of rebellion and also often encountered individuals who take responsibility. In this phase, early adults developed their independence and were required to be able to face the consequences of their actions.

These results were also in line with previous studies (Bitsko et al., 2018; Hadjimina \& Furnham, 2017; Jurewicz, 2015). A study stated that the average level of anxiety and depression in the group was directly proportional to the age group. The study reported the average score of depression for the 6-11 year age group was $1.5(1.2-1.8)$ while the 12-17 year age group was 4.0 (3.5-4.5). Furthermore, the average anxiety score for the 6-11 year age group was 4.1 (3.7-4.6) while the 12-17 year age group was 6.5 (6.0-7.2) (Bitsko et al., 2018). Younger adults reported lower levels of anxiety than older adults (Jurewicz, 2015). 
Given these characteristics, late adolescents and early adulthood had a greater opportunity to experience mental health disorders, especially during the Covid-19 pandemic. They must be held accountable for taking an active role in the prevention and mitigation of the COVID19 epidemic by limiting their activities, creativity, and innovation (Jurewicz, 2015; Talevi et al., 2020). These results also indicated that the level of mental health and anxiety of students was dependent on their age. These results were supported by previous studies which suggested that age groups tended to have an effect on levels of mental health and anxiety (Bitsko et al., 2018; Hadjimina \& Furnham, 2017). A study revealed that the difference between mental health levels in the age groups was revealed to be statistically significant, where younger age groups (18-29 years) had better mental health literacy. Consequently, this age group had better knowledge and beliefs about mental disorders that aid in the recognition, management, or prevention of mental health better than the older age group (Hadjimina \& Furnham, 2017). Differences in age groups resulted in differences in the mean levels of depression and anxiety (Bitsko et al., 2018).

Thus, it can be concluded that the age level of students had a positive and statistically significant effect on their mental health in dealing with the crisis due to the COVID-19 pandemic. In addition, the level of age also significantly influenced students' anxiety levels. The closure of schools and the lack of opportunities to interact with peers allowed the emergence of suicide ideas among adolescents due to the Covid-19 pandemic, where the idea of suicide is one of the main mental health risks. With a higher level of anxiety, the concentration of student learning tended to decrease so that it has an impact on learning achievement. Anxiety can have a negative effect on academic achievement (Haciomeroglu, 2017; H. S. Savage et al., 2020). Students' anxiety impaired the effective functioning of their attention systems and increased the extent to which processing efficiency was dependent on attention control. This explained the effect of anxiety on students' attention processes and cognitive function (Al Majali, 2020). Based on observations and interviews, it was found that almost all respondents expressed boredom due to their limited space during the COVID-19 pandemic. However, they were aware that social distancing policies were important to be followed to reduce the spread of COVID-19. The interviews also indicated that almost all respondents said they were afraid that COVID-19 would last long. These findings were supported by previous reports. COVID-19 might negatively affect mental health and wellbeing, such as experiencing fears of the consequences of new viral infections and triggering stigma (Ho et al., 2020; Xiang et al., 2020). Those who were isolated (quarantined) may experience boredom, loneliness, and anger (Fatimah \& Mahmudah, 2020; UNICEF, 2020; Usher et al., 2020; Xiang et al., 2020).

Broadly speaking, the results of observations and interviews related to learning from home produced several important things: 1) lack of time to sleep because of too many school works; 2) too much time in front of a cell phone or laptop that caused a lack of quality interaction with family; 3 ) increased laziness and decreased motivation to study; 4) difficult to concentrate and lose focus on the lesson; 5) feeling tired easily and quickly; and 6) poor time management in learning and living. Also, almost all respondents stated that the internet network was often an obstacle in the home learning system. This result was also in accordance with previous research, where the pandemic gave difficulties to students in carrying out the learning process who were forced to use e-learning (Elfaki et al., 2019; Fatimah \& Mahmudah, 2020). The Covid-19 outbreak had alarming implications for the health of individuals and society. Levels of anxiety and mental health in students had been detected. Moreover, the Covid-19 pandemic had exacerbated their symptoms. The various uncertainties caused by restrictions during the Covid-19 pandemic have caused students to feel even more anxious and depressed (Browning et al., 2021; Zajacova et al., 2020). Too many school assignments that accumulate caused them to be psychologically worse off. Differences in the age groups of students turned out to have a quite striking impact on their tendency to experience anxiety which could lead to disruption of their mental health. This was not surprising, as mental health was usually linked to anxiety and depression. Interestingly, students in the youngest age group (less than 15 years), which was called the early adolescent group, had lowest levels of anxiety as well as mental health. Usually, this 
age can be categorized as emotionally immature in dealing with emergency situations such as COVID-19. Qualitative data from observations and interviews found that they tended to be indifferent and did not really understand the consequences of the Covid-19 pandemic. Most of them only think about the weight of their schoolwork and their boredom.

Meanwhile, older groups of students, especially the early adulthood group may have better control over emotions and feelings. However, they also had a good understanding of the outbreak of Covid-19 and all its consequences. As a result, they also think about the dangers and uncertainties that may hit not only them but also those closest to them. These thoughts caused the older age groups more likely to feel anxious and depressed so that their mental health was hampered. Having good mental health was closely related to higher life satisfaction. It had a positive influence on the individual's life satisfaction. Better mental health made a person's life happier. Conversely, poor mental health caused a person's life unhappy. A study reported there was a significant and consistent correlation between mental health and life satisfaction (Fináncz et al., 2020; Wu et al., 2020). Therefore, it was a necessity to always maintain the life satisfaction of students who study at home during the COVID-19 pandemic. Various efforts were needed from various parties, including students, parents, teachers, schools and the environment. Creativity and patience were important to make students happy and comfortable while studying at home. Their happiness reduced their levels of anxiety and depression and at the same time improved their mental health.

\section{Conclusions and Suggestions}

The analysis results showed that the Covid-19 pandemic harmed students' mental health, where it tended to decline. Empirical evidence suggested that the age group of students had a positive and significant effect on their level of mental health and anxiety. Further, the empirical results also showed that respondents' anxiety levels tended to rise during the outbreak. Younger students were most affected by mental health when older students tended to be able to suppress anxiety during this crisis. Having good mental health was closely related to higher life satisfaction. It had a positive influence on the individual's life satisfaction.

\section{References}

Al Majali, S. (2020). Positive Anxiety and its Role in Motivation and Achievements among University Students. International Journal of Instruction, 13(4). https://doi.org/10.29333/iji.2020.13459a.

Ardan, M., Rahman, F. F., \& Geroda, G. B. (2020). The influence of physical distance to student anxiety on COVID-19, Indonesia. Journal of Critical Reviews, 7(17), 11261132. https://doi.org/10.31838/jcr.07.17.141.

Bao, X., Qu, H., Zhang, R., \& Hogan, T. P. (2020). Modeling Reading Ability Gain in Kindergarten Children during COVID-19 School Closures. International Journal of Environmental Research and Public Health, 17(17), 6371. https://doi.org/10.3390/ijerph17176371.

Bitsko, R. H., Holbrook, J. R., Ghandour, R. M., Blumberg, S. J., Visser, S. N., Perou, R., \& Walkup, J. T. (2018). Epidemiology and impact of health care provider-diagnosed anxiety and depression among US children. Journal of Developmental and Behavioral Pediatrics: JDBP, 39(5), 395. https://doi.org/10.1097\%2FDBP.0000000000000571.

Bodrud-Doza, M., Shammi, M., Bahlman, L., Islam, A. R. M., \& Rahman, M. (2020). Psychosocial and socio-economic crisis in Bangladesh due to COVID-19 pandemic: a perception-based assessment. Frontiers in Public Health, 8, 341. https://doi.org/10.3389/fpubh.2020.00341.

Browning, M. H. E. M., Larson, L. R., Sharaievska, I., Rigolon, A., McAnirlin, O., Mullenbach, L., Cloutier, S., Vu, T. M., Thomsen, J., Reigner, N., Metcalf, E. C., D’Antonio, A., Helbich, M., Bratman, G. N., \& Alvarez, H. O. (2021). Psychological impacts from COVID-19 among university students: Risk factors across seven states in the United 
States. PloS One, 16(1), e0245327. https://doi.org/10.1371/journal.pone.0245327.

Creswell, J. W., \& Creswell, D. J. (2018). Research design: Qualitative, quantitative, and mixed methods approaches. United Kingdom, UK. SAGE Publications, Inc.

Cullen, W., Gulati, G., \& Kelly, B. D. (2020). Mental health in the Covid-19 pandemic. QJM: An International Journal of Medicine, 113(5), 311-312. https://doi.org/10.1093/qjmed/hcaa110.

Elfaki, N. K., Abdulraheem, I., \& Abdulrahim, M. R. (2019). Impact of e-learning vs traditional learning on students' performance and attitude. International Journal of Medical Research \& Health Sciences, 8(10), 76-82.

Fatimah, S., \& Mahmudah, U. (2020). How E-Learning Affects Students' Mental Health During Covid-19 Pandemic: An Empirical Study. DWIJA CENDEKIA: Jurnal Riset Pedagogik, 4(1), 114-124. https://doi.org/10.20961/jdc.v4i1.41991.

Fináncz, J., Nyitrai, Á., Podráczky, J., \& Csima, M. (2020). Connections between Professional Well-Being and Mental Health of Early Childhood Educators. International Journal of Instruction, 13(4). https://doi.org/10.29333/iji.2020.13445a.

Gavin, B., Lyne, J., \& McNicholas, F. (2020). Mental health and the COVID-19 pandemic. Irish Journal of Psychological Medicine, 37(3), 156-158. https://doi.org/10.1017/ipm.2020.72.

Haciomeroglu, G. (2017). Reciprocal Relationships between Mathematics Anxiety and Attitude towards Mathematics in Elementary Students. Acta Didactica Napocensia, 10(11), 59-68. https://doi.org/10.24193/adn.10.3.6.

Hadjimina, E., \& Furnham, A. (2017). Influence of age and gender on mental health literacy of anxiety disorders. Psychiatry Research, 251, 8-13. https://doi.org/10.1016/j.psychres.2017.01.089.

Hamadani, J. D., Hasan, M. I., Baldi, A. J., Hossain, S. J., Shiraji, S., Bhuiyan, M. S. A., Mehrin, S. F., Fisher, J., Tofail, F., \& Tipu, S. M. M. U. (2020). Immediate impact of stay-at-home orders to control COVID-19 transmission on socioeconomic conditions, food insecurity, mental health, and intimate partner violence in Bangladeshi women and their families: an interrupted time series. The Lancet Global Health, 8(11), e1380-e1389. https://doi.org/10.1016/S2214-109X(20)30366-1.

Ho, C. S. H., Chee, C. Y., \& Ho, R. C. (2020). Mental health strategies to combat the psychological impact of COVID-19 beyond paranoia and panic. Ann Acad Med Singapore, 49(1), 1-3. https://doi.org/10.1111/wvn.12439.

Jurewicz, I. (2015). Mental health in young adults and adolescents-supporting general physicians to provide holistic care. Clinical Medicine, 15(2), 151. https://doi.org/10.7861/clinmedicine.15-2-151.

Lahav, Y. (2020). Psychological distress related to COVID-19-the contribution of continuous traumatic stress. Journal of Affective Disorders, 277, 129-137. https://doi.org/10.1016\%2Fj.jad.2020.07.141.

Lee, J. (2020). Mental health effects of school closures during COVID-19. The Lancet Child \& Adolescent Health, 4(6), 421. https://doi.org/10.1016/S2352-4642(20)30109-7.

Lima, C. K. T., de Medeiros Carvalho, P. M., Lima, I. de A. S., de Oliveira Nunes, J. V. A., Saraiva, J. S., de Souza, R. I., da Silva, C. G. L., \& Neto, M. L. R. (2020). The emotional impact of Coronavirus 2019-nCoV (new Coronavirus disease). Psychiatry Research, 112915. https://doi.org/10.1016/j.psychres.2020.112915.

Mahriza, R., Rahmah, M., \& Santi, N. E. (2020). Stop Bullying: Analisis Kesadaran dan Tindakan Preventif Guru pada Anak Pra Sekolah. Jurnal Obsesi : Jurnal Pendidikan Anak Usia Dini, 5(1), 891-899. https://doi.org/10.31004/obsesi.v5i1.739.

Martin, E. G., \& Sorensen, L. C. (2020). Protecting the health of vulnerable children and adolescents during COVID-19-related K-12 school closures in the US. JAMA Health Forum, 1(6), e200724-e200724. https://doi.org/10.1001/jamahealthforum.2020.0724.

Mechili, E. A., Saliaj, A., Kamberi, F., Girvalaki, C., Peto, E., Patelarou, A. E., Bucaj, J., \& Patelarou, E. (2020). Is the mental health of young students and their family members affected during the quarantine period? Evidence from the COVID-19 pandemic in Albania. Journal of Psychiatric and Mental Health Nursing. 
https://doi.org/10.1111/jpm.12672

Megatsari, H., Laksono, A. D., Ibad, M., Herwanto, Y. T., Sarweni, K. P., Geno, R. A. P., \& Nugraheni, E. (2020). The community psychosocial burden during the COVID-19 pandemic in Indonesia. Heliyon, 6(10), e05136. https://doi.org/10.1016/j.heliyon.2020.e05136.

Mekonnen, H., Medhin, G., Tomlinson, M., Alem, A., Prince, M., \& Hanlon, C. (2020). Impact of child emotional and behavioural difficulties on educational outcomes of primary school children in Ethiopia: a population-based cohort study. Child and Adolescent Psychiatry and Mental Health, 14, 1-10. https://doi.org/10.1186/s13034-020-00326-6.

Moreno, C., Wykes, T., Galderisi, S., Nordentoft, M., Crossley, N., Jones, N., Cannon, M., Correll, C. U., Byrne, L., \& Carr, S. (2020). How mental health care should change as a consequence of the COVID-19 pandemic. The Lancet Psychiatry. https://doi.org/0.1016/s2215-0366(20)30307-2.

Muhammad, M. (2019). Aspek Perlindungan Anak Dalam Tindak Kekerasan (Bullying) Terhadap Siswa Korban Kekerasan Di Sekolah (Studi Kasus di SMK Kabupaten Banyumas). Journal of Dinamika Hukum, 9(3). https://doi.org/10.20884/1.jdh.2009.9.3.234.

Pieh, C., Budimir, S., \& Probst, T. (2020). The effect of age, gender, income, work, and physical activity on mental health during coronavirus disease (COVID-19) lockdown in Austria. Journal of Psychosomatic Research. https://doi.org/10.1016/j.jpsychores.2020.110186.

Pierce, M., Hope, H., Ford, T., Hatch, S., Hotopf, M., John, A., Kontopantelis, E., Webb, R., Wessely, S., \& McManus, S. (2020). Mental health before and during the COVID-19 pandemic: a longitudinal probability sample survey of the UK population. The Lancet Psychiatry, 7(10), 883-892. https://doi.org/10.1016/s2215-0366(20)30308-4.

Putri, L. A. D., Yetti, E., \& Hartati, S. (2020). Pengaruh Keterlibatan Orangtua dan Regulasi Diri terhadap Perilaku Bullying Anak Usia Dini. Jurnal Obsesi: Jurnal Pendidikan Anak Usia Dini, 4(2). https://doi.org/10.31004/obsesi.v4i2.438.

Ransing, R., Adiukwu, F., Pereira-Sanchez, V., Ramalho, R., Orsolini, L., Teixeira, A. L. S., Gonzalez-Diaz, J. M., da Costa, M. P., Soler-Vidal, J., \& Bytyçi, D. G. (2020). Mental Health Interventions during the COVID-19 Pandemic: A Conceptual Framework by Early Career Psychiatrists. Asian Journal of Psychiatry, 51, 102085. https://doi.org/10.1016\%2Fj.ajp.2020.102085.

Saha, A., Dutta, A., \& Sifat, R. I. (2021). The mental impact of digital divide due to COVID-19 pandemic induced emergency online learning at undergraduate level: Evidence from undergraduate students from Dhaka City. Journal of Affective Disorders, 294(1). https://doi.org/10.1016/j.jad.2021.07.045.

Savage, H. S., Davey, C. G., Fullana, M. A., \& Harrison, B. J. (2020). Threat and safety reversal learning in social anxiety disorder - an fMRI study. Journal of Anxiety Disorders, 76, 102321. https://doi.org/10.1016/j.janxdis.2020.102321.

Savage, M. J., James, R., Magistro, D., Donaldson, J., Healy, L. C., Nevill, M., \& Hennis, P. J. (2020). Mental health and movement behaviour during the COVID-19 pandemic in UK university students: Prospective cohort study. Mental Health and Physical Activity, 19, 100357. https://doi.org/10.1016/j.mhpa.2020.100357.

Singh, S., Roy, M. D., Sinha, C. P. T. M. K., Parveen, C. P. T. M. S., Sharma, C. P. T. G., \& Joshi, C. P. T. G. (2020). Impact of COVID-19 and lockdown on mental health of children and adolescents: A narrative review with recommendations. Psychiatry Research, 113429. https://doi.org/10.1016\%2Fj.psychres.2020.113429.

Son, C., Hegde, S., Smith, A., Wang, X., \& Sasangohar, F. (2020). Effects of COVID-19 on college students' mental health in the United States: Interview survey study. Journal of Medical Internet Research, 22(9), e21279.

Suryani, A. M. (2016). Mengapa Anak Bungkam Atas Pengalaman Kekerasan Seksual? Syndrom Penyesuian Diri Roland Summit: Implementasi Di Indonesia. Buletin Psikologi, 17(1). https://doi.org/10.22146/bpsi.11481.

Talevi, D., Socci, V., Carai, M., Carnaghi, G., Faleri, S., Trebbi, E., di Bernardo, A., Capelli, 
F., \& Pacitti, F. (2020). Mental health outcomes of the CoViD-19 pandemic. Rivista Di Psichiatria, 55(3), 137-144. https://doi.org/10.1708/3382.33569.

Torales, J., O'Higgins, M., Castaldelli-Maia, J. M., \& Ventriglio, A. (2020). The outbreak of COVID-19 coronavirus and its impact on global mental health. International Journal of Social Psychiatry, 0020764020915212 . https://doi.org/10.1177/0020764020915212.

UNICEF. (2019). Technical Note: Protection of Children during the Coronavirus Pandemic (v.1) 1.

UNICEF. (2020). COVID-19 and Children in Indonesia: An agenda for action to address socio-economic challenges / Resource Centre.

Usher, K., Bhullar, N., \& Jackson, D. (2020). Life in the pandemic: Social isolation and mental health. Journal of Clinical Nursing. https://doi.org/10.1111/jocn.15290.

Van Lancker, W., \& Parolin, Z. (2020). COVID-19, school closures, and child poverty: a social crisis in the making. The Lancet Public Health, 5(5), e243-e244. https://doi.org/10.1016/S2468-2667(20)30084-0.

Wang, X., Hegde, S., Son, C., Keller, B., Smith, A., \& Sasangohar, F. (2020). Investigating mental health of us college students during the covid-19 pandemic: cross-sectional survey study. Journal of Medical Internet Research, 22(9), e22817. https://doi.org/10.2196/22817.

WHO. (2011). Mental health: a state of well-being.

WHO. (2020). Helping children cope with stress during the 2019-nCoV outbreak. Online: Https://Www. Who. Int/Docs/Default-Source/Coronaviruse/Helping-Children-CopeWithstress-Print. Pdf. .

Wu, M., Xu, W., Yao, Y., Zhang, L., Guo, L., Fan, J., \& Chen, J. (2020). Mental health status of students' parents during COVID-19 pandemic and its influence factors. General Psychiatry, 33(4). https://doi.org/10.1136\%2Fgpsych-2020-100250.

Xiang, Y.-T., Yang, Y., Li, W., Zhang, L., Zhang, Q., Cheung, T., \& Ng, C. H. (2020). Timely mental health care for the 2019 novel coronavirus outbreak is urgently needed. The Lancet Psychiatry, 7(3), 228-229. https://doi.org/10.1016/s2215-0366(20)30046-8.

Zajacova, A., Jehn, A., Stackhouse, M., Choi, K. H., Denice, P., Haan, M., \& Ramos, H. (2020). Mental health and economic concerns from March to May during the COVID19 pandemic in Canada: Insights from an analysis of repeated cross-sectional $\begin{array}{lllll}\text { surveys. SSM - Population Health, } & 100704 .\end{array}$ https://doi.org/10.1016/j.ssmph.2020.100704.

Zhai, Y., \& Du, X. (2020). Addressing collegiate mental health amid COVID-19 pandemic. Psychiatry Research, 113003. https://doi.org/10.1016/j.psychres.2020.113003. 